\title{
FOLLICULAR DEVELOPMENT, GONADAL MORPHOMETRY AND HORMONAL PROFILE OF LATE PRODUCTION LAYERS FED VARIED SUPPLEMENTAL LEVELS OF ACETYLSALICYLIC ACID
}

\author{
Awoneye, Olusola O.; Olusegun, Olawumi B; Owolabi, Olamide T. \\ Department of Animal Health and Production, Rufus Giwa \\ Polytechnic, PMB1019, Owo Ondo State, Nigeria. \\ DOI: https://doi.org/10.51193/IJAER.2021.7105
}

\begin{abstract}
This study was carried out to investigate the effect of acetylsalicylic acid on follicular development, gonadal morphometry and hormonal profile of Isa Brown and Haro Black breeds of layer. One hundred and ninety two (192) 60 weeks old layers (96Harco Black and 96 Isa Brown) were used in this study. Four treatment diets were formulated with acetylsalicylic acid at $0 \%$ (T1), $0.025 \%$ (T2), $0.050 \%$ (T3), and $0.075 \%$ (T4) inclusion levels. At the ends of 12 weeks feeding trial, 12 birds per treatment were slaughtered and the reproductive tracts were carefully removed for follicular and gonadal morphometrical examinations. Blood samples were equally collected for hormonal analysis. The result revealed that layers fed $0.075 \%$ ASA had the highest $(\mathrm{P}<0.05)$ number of follicle, weight of the entire reproductive tract, length of magnum, length of isthmus and length of shell gland, The result of the hormonal assay revealed significant breed effects $(\mathrm{P}<0.05)$ in progesterone, estradiol and cortisol. Layers fed $0.050 \%$ ASA were observed to have the highest progesterone and estradiol values. It could be concluded that supplementation of acetylsalicylic acid up to $0.050 \%$ in layer's diet has a significant effect in stimulating follicular growth and modulating the functionality of the oviduct.
\end{abstract}

Keywords: Acetylsalicylic acid, follicular development, oviduct, Isa Brown, Harco Black

\subsection{INTRODUCTION}

Ovarian follicles are the structural and functional unit of the ovary, which contains the gamete (the oocyte) and supportive somatic cells. It also secretes important hormones necessary for proper endocrine function, Ovarian folliculogenesis involves varying range of cellular processes starting from primordial follicle which develops into fully mature and competent oocyte, which is ovulated and becomes available for fertilization (Oktem, and Urman, 2010). This process is influenced by many physiological factors, most especially those associated with hypothalamic- 
International Journal of Agriculture and Environmental Research

ISSN: 2455-6939

Volume: 07, Issue: 01 "January-February 2021"

pituitary-gonadal (HPG) axis. The HPG axis controls the secretion of hormones that brings about cyclical changes in the reproductive organs. The secreted hormones, beginning with gonadotropin-releasing hormone $(\mathrm{GnRH})$ from the hypothalamus, as well as downstream hormones follicle-stimulating hormone (FSH), luteinizing hormone (LH), estrogen, progesterone, and others, become particularly important during the pre-ovulatory stage of folliculogenesis,. It has been reported that all these processes are negatively influenced by high environmental temperature concentrations (Garriga et al., 2006; Quinteiro-Filho, 2010; Quinteiro-Filho, 2012). It is therefore imperative to investigate on management strategies to combat this problem in layer's production.

High environmental temperature, humidity and global warming has been reported to have detrimental effect on poultry production (St-Pierre et al., 2003; Piestun et al., 2013). Investigation indicates that heat stress induces serious intra-corporal damages even if the animal survives (Kamboh et al., 2013). When domestic chickens are exposed to high temperature, its' cells fail to produce adequate heat-shock proteins (Hsps) expression, which is important in protecting animals against heat stress.. Several authors mentioned that birds reared under heat stress condition have been associated with decrease in egg production (Corzo et al., 2009; ElTarabany, 2016), egg weight (Fouad et al.,2016), egg quality (Franco-Jimenez et al.,2007), shell quality (Gowe and Fairfull, 2008), protein digestion (Corzoet al., 2009), feed digestibility and body weight (Grieve, 2003) of laying hens. El-Tarabany (2016) also reported the negatively influenced of high environmental temperature on steroid hormones. Hence, the need to find possible ways to alleviate this problem in poultry production. One of the way to achieve this is to carry out more researches on compounds that induce heat shock protein expression. One of such compound is acetylsalicylic acid.

Aspirin, or acetyl salicylic acid (ASA) is a derivative of salicylate was the first non-steroidal anti-inflammatory drug to be discovered, and is generally used as an analgesic, to reduce fever (an antipyretic), and also as an anti-inflammatory drug. Aspirin is part of a group of medications called non-steroidal anti-inflammatory drugs (NSAIDs), but differs from most other NSAIDs by irreversible inhibiting enzyme cyclo-oxygenase (COX). Few reports are available on the effect of dietary aspirin on laying hens. Balog and Hester (1991) reported that feeding 0.05\% ASA to aged layer breeders for periods of four weeks reduced production of shellless eggs. In addition, feeding ASA to hens during heat stress conditions improves egg quality and egg production (Reid et al., 1964; Oluyemi and Adebanjo, 1979), but the effect of acetylsalicylic acid on follicular development gonadal morphometry and hormonal profile of late production layers has not been fully exhausted, hence this research was conducted to investigate the influence of acetylsalicylic acid on follicular development, organ morphometry and hormonal status of layers. 


\subsection{MATERIALS AND METHODS}

\subsection{Experimental site}

The feeding trials was carried out at the Teaching and Research Farm of the Department of Animal Production and Health, The Federal University of Technology Akure (Latitude $7^{\circ} 15^{\prime}$ 9.22” N and longitude $5^{\circ} 11^{\prime} 35.23$ 'E), Ondo State, Nigeria. The experimental site is located in southwestern Nigeria, where the climate is influenced by the rain-bearing Southwest monsoon winds from the Atlantic Ocean and dry Northeast trade wind from the Sahara Desert. The rainy season lasts for about seven months with about $1524 \mathrm{~mm}$ of rainfall per annum. The atmospheric temperature ranges between $26^{\circ} \mathrm{C}$ and $31^{\circ} \mathrm{C}$, with mean annual relative humidity of about $80 \%$ (Climatic Data, 2018).

\subsection{Experimental additive}

Aspirin (Acetylsalicyclic acid) used in this study was purchased from a reliable Pharmaceutical store in Akure Town of Ondo State, Nigeria.

\subsection{Experimental Birds and Management Practices}

One hundred and ninety two layers (96 Isa Brown and 96 Harco Black breeds) of 60 weeks old were used for this experiment. Prior to the arrival of the birds, the pen was swept, washed, and disinfected. On the arrival of the birds, they were given anti-stress (Vitalyte) and seven days physiological adjustment to the feed and environment before data collection. The layers were kept in battery cages equipped with drinkers and detachable feeding troughs. Good hygienic condition was maintained throughout the period of the feeding trial.

\subsection{Experimental Diets and Layout}

Four treatment diets were formulated. Diet 1 (T1) which is the control had no inclusion of Acetyl salicylic acid (ASA), Diet 2 (T2) contained $0.025 \%$ ASA, Diet 3 (T3) contained 0.050\% ASA and Diet 4 (T4) had $0.075 \%$ of ASA. The layers were randomly divided into four dietary treatments; each treatment comprising 48 birds, which was replicated 4 times with 12 birds per replicate, Layer's feed was formulated to meet the nutrient requirement of the birds (NRC, 1998). and each layer was fed with 113g of layer's diet per day. Table 1 shows the gross composition of the layer's diets. 
Table 1: Composition (g/100g) of experimental diets for layers $\left(21^{\text {st }}-7^{\text {rd }}\right.$ weeks of age)

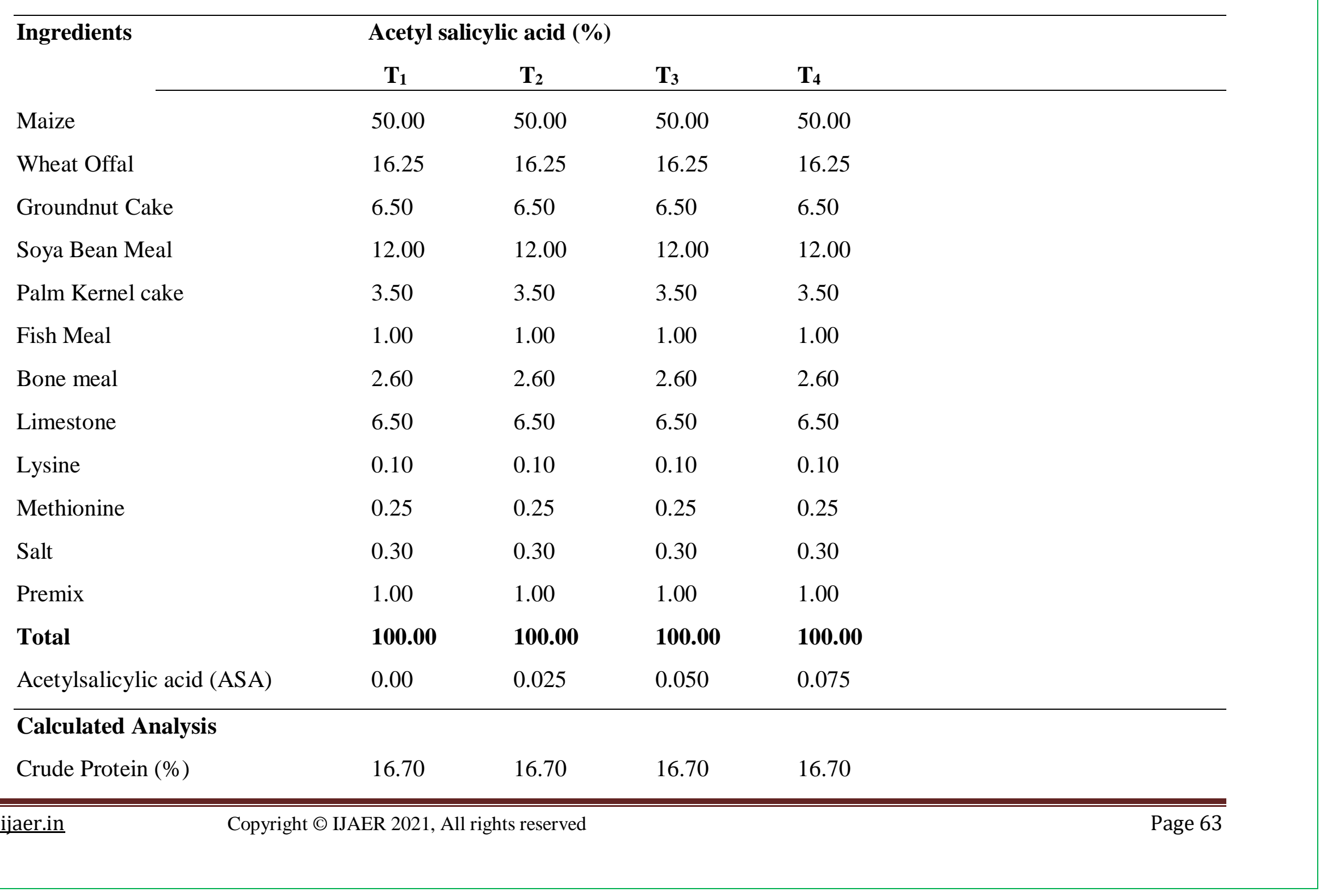


International Journal of Agriculture and Environmental Research

ISSN: 2455-6939

Volume: 07, Issue: 01 "January-February 2021"

$\begin{array}{lllll}\text { Metabolizable Energy (MJ/Kg) } & 10.50 & 10.50 & 10.50 & 10.50 \\ \text { Ether Extract (\%) } & 4.21 & 4.21 & 4.21 & 4.21 \\ \text { Crude Fibre (\%) } & 4.48 & 4.48 & 4.48 & 4.48 \\ \text { Phosphorus (\%) } & 0.94 & 0.94 & 0.94 & 0.94 \\ \text { Calcium (\%) } & 3.32 & 3.32 & 3.32 & 3.32 \\ \text { Lysine (\%) } & 0.86 & 0.86 & 0.86 & 0.86 \\ \text { Methionine (\%) } & 0.53 & 0.53 & 0.53 & 0.53\end{array}$

T1 = Diet with $0.00 \%$ ASA; T2 = Diet with 0.025\% ASA; T3 = Diet with 0.050\% ASA; T4 = Diet with 0.075\% ASA 
International Journal of Agriculture and Environmental Research

ISSN: 2455-6939

Volume: 07, Issue: 01 "January-February 2021"

\subsection{Data Collection}

\subsubsection{Gonadal morphometry}

At the end of the feeding trial, 48 hens (12 birds per treatment) were randomly selected, slaughtered and dissected. The reproductive tract was carefully removed, the various parts of the reproductive organs such as the ovary, infundibulum, magnum, isthmus, uterus, vagina and the entire reproductive tract were weighed and measured accordingly. The weights and lengths were taken using sensitive scale and measuring tape respectively.

\subsubsection{Follicular Development}

The follicles in each bird were counted, measured with digital calipers and recorded. The follicles were divided into matured/Graafian follicles; stage 3 pre-ovulatory or maturing follicles; stage 2 pre-ovulatory follicles; stage1 pre-ovulatory follicles and pre-vitellogenic follicles according to (Myers et al., 2004).

\subsubsection{Hormonal Examination}

Blood samples for hormonal examination were collected from the birds after slaughtering into test tubes which were held in a slanted form for about 12 hours for clotting to take place. From the clotted blood, sera were separated following centrifugation at 3000rpm for about 10 minutes. Hormonal Assay was carried out at Chemical Pathology Department of University College Hospital (UCH) Ibadan in Oyo State where an enzyme based immunoassay procedure was employed to determine oestradiol, progesterone, testosterone, cortisol, and luteinizing hormone in the serum samples. The protocol used for the analysis was as described by the test kit producers. A ST AIA-PACK E2 kit, (cat. no 0025224, Medesa, CZ), was used for the quantitative determination of estradiol in the sera. The kit is a competitive enzyme immunoassay, which was performed entirely in AIA-PACK test cups. Estradiol present in the test sample competes with enzyme-labeled $\mathrm{E}_{2}$ for a limited number of binding sites on an anti- E2 monoclonal antibody immobilized on magnetic beads. The magnetic beads were washed to remove any unbound enzyme-labelled E2 and then incubated with the fluorogenic substrate 4methylumbelliferylphosphate (4 MUP). The amount of enzyme-labelled E2 that binds to the beads is inversely proportional to the estradiol concentration in the test sample. A standard curve was constructed, and unknown estradiol concentrations were calculated using this curve. The Tosoh AIA System Analyser (Tosoh Bioscience, USA) was used to read the rate of the fluorescence produced by the reaction, and to automatically convert the rate to estradiol concentration in $\mathrm{mIU} / \mathrm{ml}$ (protocol ST AIA-PACK iE2). All the hormonal parameters were determined using the same procedure. The luteinizing hormone was determined using A ST AIA-PACK LH II kit, (cat. no 0025296, Medesa, CZ), while quantitative determination of the 
progesterone in the sera was carried out using A ST AIA-PACK PROG kit, (cat. no 0025281, Medesa,CZ). A ST AIA-PACK Testosterone kit, (cat. no 0025204, Medesa, CZ), was used for the quantitative determination of testosterone in the sera and determination of Cortisol was done using A ST AIA-PACK CORT kit, (cat. no 0025287, Medesa, CZ),

Statistical Analysis Data obtained from layers were subjected to 2 x 4 factorial analyses in a completely randomized design, according to the procedure of SAS (2008). Duncan s multiple range Test of the same statistical package was used to compare the means.

\subsection{RESULT AND DISCUSSION}

\subsection{The Morphometrics of the Reproductive Tracts of Laying Hens Fed Varied Supplemental Levels of Acetylsalicylic Acid}

The morphological knowledge of reproductive tract is very much essential to the commercial producers and breeders for the production of egg and meat-type chickens. The morphometrics of the reproductive tracts of laying hens fed varied supplemental levels of acetylsalicylic acid is is as shown in Table 2. It was observed that Harco Black had significantly higher $(\mathrm{P}<0.05)$ weight of the entire length of the reproductive tract, weight of the ovary, length of magmum, length of isthmus, length of shell gland and length of vagina, while significantly higher $(\mathrm{P}<0.05)$ length of infundibulum was recorded in Isa Brown. Significant differences $(\mathrm{P}<0.05)$ were also observed in all the parameters among the treatments, with layers fed $0.075 \%$ ASA having the highest weight of the entire reproductive tract of $83.50 \pm 8.90 \mathrm{~g}$. It was also observed that layers fed $0.025 \%$ ASA had a significantly higher $(\mathrm{P}<0.05)$ weight of the ovary $(25.60 \pm 2.12 \mathrm{~g})$ which was statistically the same $(\mathrm{P}>0.05)$ as the value obtained in layers fed $0.075 \%$ ASA with value of $24.33 \pm 4.36 \mathrm{~g}$. Significantly higher $(\mathrm{P}<0.05)$ length of magmum, length of isthmus and length of shell gland values were also recorded in birds fed $0.075 \%$ ASA. The higher weight of the entire reproductive tract and ovary recorded in Harco Black breed and in ASA supplemented diets, indicates high modulation of gonadotropin-releasing hormone from the hypothalamus, which enhances the production of follicle-stimulating hormone (FSH) and luteinizing hormone (LH) (Osinowo, 2006) and subsequent stimulation of ovary to produce oestrogen. High production of oestrus has been reported to increase ovarian weight (Iwu et al 2013). The values of the length of the isthmus, shell gland and vagina obtained in this study was in agreement with the values reported by Ahmad-Ali Mohammadpour et al. (2012), but was lower than the value obtained by Aro, (2019), the differences could be as a result of different in nutrition, breeds of layer, management practices and the environment. 
Volume: 07, Issue: 01 "January-February 2021"

Table 2: Morphometrics of the reproductive tracts of laying hens fed varied supplemental levels of acetylsalicylic acid (ASA)

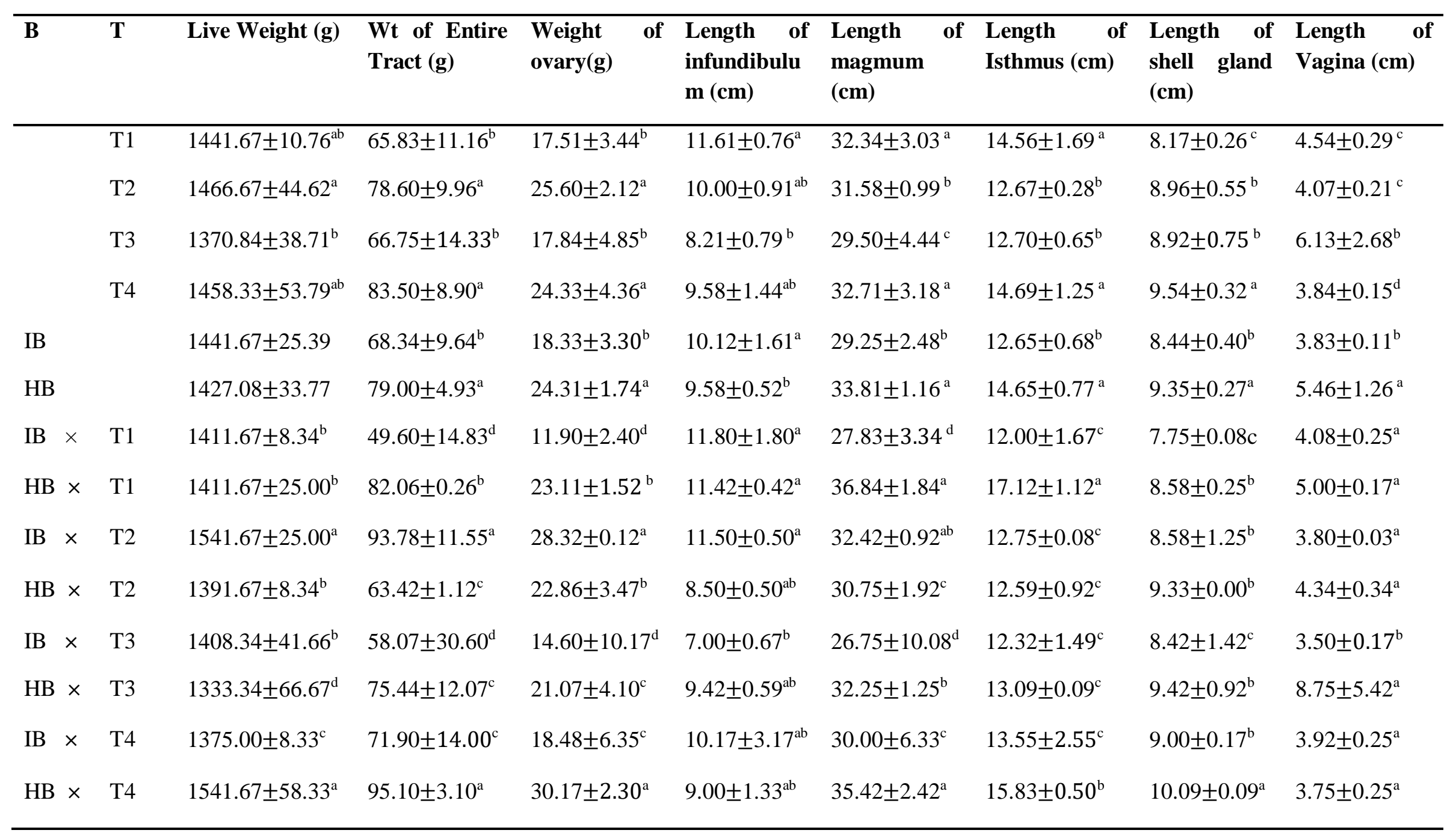


Volume: 07, Issue: 01 "January-February 2021"

\begin{tabular}{|c|c|c|c|c|c|c|c|c|}
\hline$\overline{\mathrm{T}}$ & $*$ & * & $*$ & * & $*$ & $*$ & $*$ & $*$ \\
\hline B & $*$ & $*$ & $*$ & $*$ & $*$ & $*$ & $*$ & $*$ \\
\hline $\mathrm{B} \times \mathrm{T}$ & $*$ & $*$ & $*$ & $*$ & $*$ & $*$ & $*$ & $*$ \\
\hline
\end{tabular}

$\mathrm{a}, \mathrm{b}, \mathrm{ab}, \mathrm{c}, \mathrm{d}=$ Means on the same column for each factor and their interactions, but with different superscripts are statistically $(\mathrm{P}<0.05)$ Significant. T1 = Diet with 0.00\% ASA; T2 = Diet with 0.025\% ASA; T3 = Diet with 0.050\% ASA; T4 = Diet with 0.075\% ASA; NS = Not significant $*$ * Significant at $0.05 \%$; B = Breed; T= Treatment $\mathrm{B} \times \mathrm{T}=$ Breed $\times$ Treatment; HB =Harco Black; IB = Isa Brown 
International Journal of Agriculture and Environmental Research

ISSN: 2455-6939

Volume: 07, Issue: 01 "January-February 2021"

\subsection{Number of Follicles of Late Production layers Fed Varied Levels of Acetylsalicylic Acid}

Table 3 showed the number of follicles of layer fed varied supplemental levels of acetylsalicylic acid.. There were no significant differences $(\mathrm{P}>0.05)$ in the pre-ovulatory follicle 2 and 3 across the treatment, breeds of layer and in the interaction between breed and treatment, however significant treatment $(\mathrm{P}<0.05)$ effect was observed across treatments in stage 1growth of preovulatory follicle and pre-vitellogenic follicle, in which layers fed $0.075 \%$ was observed to have the highest value of $2.00 \pm 0.00$ and $43.75 \pm 1.96$ respectively, the number of pre-vitellogenic follicles obtained in layers fed $0.075 \%$ ASA was not significantly different $(\mathrm{P}>0.05)$ from layers fed $0.025 \%$ ASA. Harco Black breed had significantly $(\mathrm{P}<0.05)$ higher pre-vitelogenic value of $42.19 \pm 3.22$, whereas, no significant breed effect was observed in stage 1 pre-ovulatory follicle. The significant highest pre-vitellogenic follicle recorded in layers fed $0.025 \%$ and $0.050 \%$ ASA could be attributed to the gonadal steroid modulatory ability of acetylsalicylic acid which enhances the release of oestrogen and lead to increase in follicular growth, ovarian weight, mitotic index granulose cell (Hakan et al.,1993; Williams \& Erickson, 2000) and inhibition of granulose cell apoptosis (Mikkelsen, et al., 2001). It was also observed that the number of follicle decreased as the size of follicle increased, this is an indication of normal apoptosis which is a mandatory process in the maintenance of homeostasis of animals. This agreed with the report of Hirshfield (1991) that apoptosis is a prominent feature of ovarian follicular development which occurs throughout female reproductive life in which less than $0.1 \%$ of all follicles present at pre- vitellogenic stage mature and ovulate.

Table 3: Number of Follicles of Late Production layers Fed Varied Levels of Acetylsalicylic Acid

\begin{tabular}{|c|c|c|c|c|c|c|}
\hline $\bar{B}$ & $\mathrm{~T}$ & $\begin{array}{l}\text { Pre-vitellogenic } \\
\text { follicle }(<10 \mathrm{~mm})\end{array}$ & $\begin{array}{l}\text { Pre- Ovulatory } \\
\text { follicle } 1 \\
10-14 \mathrm{~mm})\end{array}$ & $\begin{array}{l}\text { Pre- } \\
\text { Ovulatory } \\
\text { follicle } 2 \\
(15-19 \mathrm{~mm})\end{array}$ & $\begin{array}{l}\text { Pre-ovulatory } \\
\text { follicle } 3 \text { (20- } \\
24 \mathrm{~mm})\end{array}$ & $\begin{array}{l}\text { Graffian } \\
\text { follicles } \\
(25 \mathrm{~mm} \text { and } \\
\text { above) }\end{array}$ \\
\hline & $\mathrm{T} 1$ & $41.63 \pm 2.52^{\mathrm{ab}}$ & $1.25 \pm 0.25^{\mathrm{b}}$ & $1.00 \pm 0.00$ & $1.00 \pm 0.00$ & $1.00 \pm 0.00$ \\
\hline & $\mathrm{T} 2$ & $43.03 \pm 5.33^{\mathrm{a}}$ & $1.00 \pm 0.00^{\mathrm{b}}$ & $1.00 \pm 0.00$ & $1.00 \pm 0.00$ & $1.00 \pm 0.00$ \\
\hline & $\mathrm{T} 3$ & $31.88 \pm 1.01^{\mathrm{b}}$ & $1.25 \pm 0.25^{\mathrm{b}}$ & $1.00 \pm 0.00$ & $1.00 \pm 0.00$ & $1.00 \pm 0.00$ \\
\hline & $\mathrm{T} 4$ & $43.75 \pm 1.96^{\mathrm{a}}$ & $2.00 \pm 0.00^{\mathrm{a}}$ & $1.00 \pm 0.00$ & $1.00 \pm 0.00$ & $1.00 \pm 0.00$ \\
\hline IB & & $39.45 \pm 2.53^{\mathrm{b}}$ & $1.00 \pm 0.00$ & $1.00 \pm 0.00$ & $1.00 \pm 0.00$ & $1.00 \pm 0.00$ \\
\hline $\mathrm{HB}$ & & $42.19 \pm 3.22^{\mathrm{a}}$ & $1.25 \pm 0.16$ & $1.00 \pm 0.00$ & $1.00 \pm 0.00$ & $1.00 \pm 0.00$ \\
\hline
\end{tabular}


International Journal of Agriculture and Environmental Research

ISSN: 2455-6939

Volume: 07, Issue: 01 "January-February 2021"

\begin{tabular}{cccccccc}
\hline $\mathrm{IB} \times$ & $\mathrm{T} 1$ & $43.00 \pm 4.50^{\mathrm{b}}$ & $1.50 \pm 0.50^{\mathrm{a}}$ & $1.00 \pm 0.00$ & $1.00 \pm 0.00$ & $1.00 \pm 0.00$ \\
$\mathrm{HB} \times$ & $\mathrm{T} 1$ & $40.25 \pm 3.75^{\mathrm{bc}}$ & $1.00 \pm 0.00^{\mathrm{b}}$ & $1.00 \pm 0.00$ & $1.00 \pm 0.00$ & $1.00 \pm 0.00$ \\
$\mathrm{IB} \times$ & $\mathrm{T} 2$ & $38.05 \pm 7.55^{\mathrm{c}}$ & $1.00 \pm 0.00^{\mathrm{b}}$ & $1.00 \pm 0.00$ & $1.00 \pm 0.00$ & $1.00 \pm 0.00$ \\
$\mathrm{HB} \times$ & $\mathrm{T} 2$ & $49.00 \pm 6.50^{\mathrm{a}}$ & $1.00 \pm 0.00^{\mathrm{b}}$ & $1.00 \pm 0.00$ & $1.00 \pm 0.00$ & $1.00 \pm 0.00$ \\
$\mathrm{IB} \times$ & $\mathrm{T} 3$ & $31.00 \pm 2.00^{\mathrm{d}}$ & $1.50 \pm 0.50^{\mathrm{a}}$ & $1.00 \pm 0.00$ & $1.00 \pm 0.00$ & $1.00 \pm 0.00$ \\
$\mathrm{HB} \times$ & $\mathrm{T} 3$ & $32.75 \pm 0.75^{\mathrm{d}}$ & $1.00 \pm 0.00^{\mathrm{b}}$ & $1.00 \pm 0.00$ & $1.00 \pm 0.00$ & $1.00 \pm 0.00$ \\
$\mathrm{IB} \times$ & $\mathrm{T} 4$ & $43.75 \pm 0.75^{\mathrm{b}}$ & $1.50 \pm 0.00^{\mathrm{a}}$ & $1.00 \pm 0.00$ & $1.00 \pm 0.00$ & $1.00 \pm 0.00$ \\
$\mathrm{HB} \times$ & $\mathrm{T} 4$ & $43.75 \pm 4.75^{\mathrm{b}}$ & $1.70 \pm 0.00^{\mathrm{a}}$ & $1.00 \pm 0.00$ & $1.00 \pm 0.00$ & $1.00 \pm 0.00$ \\
$\mathrm{~T}$ & & $*$ & $*$ & $\mathrm{NS}$ & $\mathrm{NS}$ & $\mathrm{NS}$ \\
$\mathrm{B}$ & & $*$ & $\mathrm{NS}$ & $\mathrm{NS}$ & $\mathrm{NS}$ & $\mathrm{NS}$ \\
$\mathrm{T}$ & & $*$ & $*$ & $\mathrm{NS}$ & $\mathrm{NS}$ & $\mathrm{NS}$ \\
\hline
\end{tabular}

$\mathrm{a}, \mathrm{b}, \mathrm{ab}, \mathrm{bc}, \mathrm{c}, \mathrm{d}=$ Means on the same column for each factor and their interactions, but with different superscripts are statistically $(\mathrm{P}<0.05)$ Significant. $\mathrm{T} 1=$ Diet with $0.00 \%$ ASA; $\mathrm{T} 2=$ Diet with $0.025 \%$ ASA; T3 = Diet with $0.050 \%$ ASA; T4 = Diet with $0.075 \%$ ASA; NS $=$ Not significant; * = Significant at $0.05 \% ; \mathrm{B}=$ Breed; $\mathrm{T}=$ Treatment $\mathrm{B} \times \mathrm{T}=$ Breed $\times$ Treatment; HB $=$ Harco Black; IB = Isa Brown.

\subsection{Dimension of Follicles of Late Production Layers Fed Varied Levels of Acetylsalicylic Acid}

The dimension of follicle of layers fed varied supplemental levels of acetylsalicylic acid is as shown in table 4 . The assessment of the dimension of follicle is based on the principle of identifying the follicles that will become atresic and those that will develop to maturity. The result revealed that there were significant treatment effects in the dimension of the follicles at three three stages of growth of pre-ovulatory follicle and in graffain follicular stage. The result obtained in this study was in line with the work of Aro, 2019 who reported a significant treatment effect in the 3 stages of pre-ovulatory development when late production layers were fed varied supplemental level of dietary salt. Layers fed $0.025 \%$ ASA was observed have the highest dimension in first stage of pre-ovulation 1 and graffian follicle with the values of $13.25 \pm 0.48 \mathrm{~mm}$ and $27.63 \pm 0.38 \mathrm{~mm}$ respectively, which were statistically similar to the values obtained in layers fed $0.075 \%$ ASA with the values of $12.83 \pm 0.90$. It was also observed that the dimension of follicle at stage 2 of pre-ovulatory follicle increased as the level of ASA supplementation increased, with layers fed $0.075 \%$ ASA having significantly highest dimension of $18.13 \pm 0.31 \mathrm{~mm}$, however, no particle trend was observed in the dimension of follicle at $3^{\text {rd }}$ 
stage of pre-ovulatory follicles. Layer fed $0.050 \%$ ASA was observed to have significantly highest dimension of $23.25 \pm 0.48 \mathrm{~mm}$. It was also observed that the dimension of the follicles in the three stages of the pre-ovulatory follicles was below the maximum range for each group across the treatments and in the two breeds of layer. The high dimension recorded in ASA supplemented diet at stage 2 and 3 pre-ovulation development is an indication of cytoplasmic maturation of the oocyte to reach a sufficient diameter and accumulate the nutrients necessary for early embryonic development (Watson, 2007) and this could be attributed to relevance of steroid hormone (oestrogen) which enhances follicular weight and dimension, hence make the follicle less vulnerable to apoptosis (Sakata et al., 2000). Breed effect was only observed in the dimension of stage 2 pre-ovulatory follicles and granffian follicle with Harco Black having the highest value of $17.31 \pm 0.53 \mathrm{~mm}$ and $27.19 \pm 0.42 \mathrm{~mm}$ respectively, whereas the two breeds were not statistically different from each in follicular dimension at stage 1 and three pre- ovulatory stages. There was significant difference in the interaction between treatment and

Table 4: Diameter of Follicles of Late Production Layers Fed Varied Levels of Acetylsalicylic Acid

\begin{tabular}{|c|c|c|c|c|c|c|}
\hline \multirow{5}{*}{\multicolumn{2}{|c|}{ B }} & $\mathrm{T}$ & $\begin{array}{l}\text { Pre- Ovulation } 1 \\
(10-14 \mathrm{~mm})\end{array}$ & $\begin{array}{l}\text { Pre- Ovulation } 2 \\
(15-19 \mathrm{~mm})\end{array}$ & $\begin{array}{l}\text { Pre-ovulation } 3 \\
(20-24 \mathrm{~mm})\end{array}$ & $\begin{array}{l}\text { Graffian } \\
\text { follicles }(25 \mathrm{~mm} \\
\text { and above })\end{array}$ \\
\hline & & $\mathrm{T} 1$ & $11.75 \pm 0.63^{b}$ & $15.38 \pm 0.24^{\mathrm{c}}$ & $21.50 \pm 0.29^{b}$ & $27.00 \pm 0.41^{\mathrm{ab}}$ \\
\hline & & $\mathrm{T} 2$ & $13.25 \pm 0.48^{\mathrm{a}}$ & $16.38 \pm 0.63^{\mathrm{bc}}$ & $22.13 \pm 0.63^{\mathrm{ab}}$ & $27.63 \pm 0.38^{\mathrm{a}}$ \\
\hline & & $\mathrm{T} 3$ & $11.50 \pm 0.20^{b}$ & $17.50 \pm 0.89^{\mathrm{ab}}$ & $23.25 \pm 0.48^{\mathrm{a}}$ & $26.00 \pm 0.41^{\mathrm{c}}$ \\
\hline & & $\mathrm{T} 4$ & $12.83 \pm 0.90^{\mathrm{ab}}$ & $18.13 \pm 0.31^{\mathrm{a}}$ & $22.25 \pm 0.48^{\mathrm{ab}}$ & $27.50 \pm 0.50^{\mathrm{a}}$ \\
\hline IB & & & $12.44 \pm 0.48$ & $16.38 \pm 0.51^{\mathrm{ab}}$ & $22.25 \pm 0.35$ & $26.88 \pm 0.30^{b}$ \\
\hline $\mathrm{HB}$ & & & $12.13 \pm 0.47$ & $17.31 \pm 0.53^{\mathrm{a}}$ & $22.31 \pm 0.43$ & $27.19 \pm 0.42^{\mathrm{a}}$ \\
\hline IB & $x$ & $\mathrm{~T} 1$ & $11.00 \pm 1.00^{\mathrm{b}}$ & $15.25 \pm 0.25^{\mathrm{c}}$ & $21.00 \pm 0.00 \mathrm{~b}$ & $27.50 \pm 0.50^{\mathrm{ab}}$ \\
\hline $\mathrm{HB}$ & $\times$ & $\mathrm{T} 1$ & $12.50 \pm 0.50^{\mathrm{a}}$ & $15.50 \pm 0.50^{c}$ & $22.00 \pm 0.00^{\mathrm{ab}}$ & $26.50 \pm 0.50^{\mathrm{b}}$ \\
\hline IB & $x$ & $\mathrm{~T} 2$ & $13.00 \pm 1.00^{\mathrm{a}}$ & $17.25 \pm 0.75^{\mathrm{ab}}$ & $22.75 \pm 0.75^{\mathrm{ab}}$ & $27.50 \pm 0.50^{\mathrm{ab}}$ \\
\hline HB & $x$ & $\mathrm{~T} 2$ & $13.50 \pm 0.50^{\mathrm{a}}$ & $15.50 \pm 0.50^{\mathrm{c}}$ & $21.50 \pm 1.00^{\mathrm{b}}$ & $27.50 \pm 0.50^{\mathrm{ab}}$ \\
\hline IB & $\times$ & $\mathrm{T} 3$ & $11.25 \pm 0.25^{\mathrm{b}}$ & $18.25 \pm 0.75^{\mathrm{a}}$ & $23.50 \pm 0.50^{\mathrm{a}}$ & $25.50 \pm 0.50^{\mathrm{b}}$ \\
\hline $\mathrm{HB}$ & $x$ & $\mathrm{~T} 3$ & $11.75 \pm 0.25^{\mathrm{ab}}$ & $16.75 \pm 1.75^{b}$ & $23.00 \pm 1.00^{\mathrm{a}}$ & $26.50 \pm 0.50^{\mathrm{b}}$ \\
\hline
\end{tabular}


International Journal of Agriculture and Environmental Research

ISSN: 2455-6939

Volume: 07, Issue: 01 "January-February 2021"

\begin{tabular}{lccccc}
\hline $\mathrm{IB} \times$ & $\mathrm{T} 4$ & $13.25 \pm 0.25^{\mathrm{a}}$ & $18.50 \pm 0.50^{\mathrm{a}}$ & $22.00 \pm 1.00^{\mathrm{ab}}$ & $28.00 \pm 0.00^{\mathrm{a}}$ \\
$\mathrm{HB} \times$ & $\mathrm{T} 4$ & $12.00 \pm 2.00^{\mathrm{ab}}$ & $17.75 \pm 0.25^{\mathrm{ab}}$ & $22.50 \pm 0.50^{\mathrm{ab}}$ & $27.00 \pm 1.00^{\mathrm{ab}}$ \\
$\mathrm{T}$ & & $*$ & $*$ & $*$ & $*$ \\
$\mathrm{~B}$ & $\mathrm{NS}$ & $*$ & $\mathrm{NS}$ & $*$ \\
$\mathrm{~T} \mathrm{X} \mathrm{B}$ & $*$ & $*$ & $*$ & $*$ \\
\hline
\end{tabular}

$\mathrm{a}, \mathrm{ab}, \mathrm{b}, \mathrm{bc}=$ Means on the same column for each factor and their interactions, but with different superscripts are statistically $(\mathrm{P}<0.05)$ Significant. $\mathrm{T} 1=$ Diet with $0.00 \%$ ASA; T2 = Diet with $0.025 \%$ ASA; T3 = Diet with $0.050 \%$ ASA; T4 = Diet with 0.075\% ASA; NS = Not significant; $*=$ Significant at $0.05 \% ; \mathrm{B}=$ Breed; $\mathrm{T}=$ Treatment $\mathrm{B} \times \mathrm{T}=$ Breed $\times$ Treatment $\mathrm{HB}=\mathrm{Harco}$ Black; IB = Isa Brown

\subsection{Hormonal profile of the laying hens fed varied supplemental levels of acetylsalicylic acid (ASA) at the $73^{\text {rd }}$ week of the experiment}

Table 5 shows the hormonal profile of the laying hens fed varied supplemental levels of acetylsalicylic acid at the $73^{\text {rd }}$ of the experiment. The result of the hormonal assay revealed significant breed effects $(\mathrm{P}<0.05)$ in progesterone, estradiol and cortisol, with Harco Black having significantly higher $(\mathrm{P}<0.05)$ progesterone and estradiol values of $0.64 \pm 0.06 \mathrm{nmol} / \mathrm{L}$ and $82.41 \pm 9.11 \mathrm{pmol} / \mathrm{L}$, while a significantly higher $(\mathrm{P}<0.05)$ cortisol was observed in Isa Brown breed with the value of $5.44 \pm 0.06 \mathrm{nmol} / \mathrm{L}$. Significant treatment effects $(\mathrm{P}<0.05)$ were also observed in all the hormonal parameters, Layers fed 0.050\% ASA had the highest progesterone and estradiol with significantly lowest $(\mathrm{P}<0.05)$ cortisol values of $0.68 \pm 0.11 \mathrm{nmol} / \mathrm{L}$ and $91.53 \pm 18.23 \mathrm{pmol} / \mathrm{L} 5.33 \pm 0.18 \mathrm{nmol} / \mathrm{L}$ respectively. The higher $(\mathrm{P}<0.05)$ value of progesterone, estradiol and testoterone recorded in layers fed $0.050 \%$ and $0.075 \%$ ASAwith lowest $(\mathrm{P}<0.05)$ cortisol value is a reflection of ASA to induce the activity of the neuro-endocrine system, which lead to production of higher amount of reproductive hormone from the hypothalamus and suppressed stress indicator hormone (cortisol) (Abou El-Soud et al., 2006; AbdelFattah, 2006).

The highest testosterone value was recorded in layers fed $0.075 \%$ ASA with the value of $0.60 \pm 0.23 \mathrm{nmol} / \mathrm{L}$. Significant differences $(\mathrm{P}<0.05)$ in the interactions between the breeds and treatments were only observed in luteinizing hormone, progesterone and testosterone. 
Table 5: Hormonal profile of the laying hens fed varied supplemental levels of acetylsalicylic acid (ASA) at the $73^{\text {rd }}$ week of the experiment

\begin{tabular}{|c|c|c|c|c|c|c|}
\hline $\mathbf{B}$ & $\mathbf{T}$ & LH(iu/L) & PROG(nmol/L) & TES(nmol/L) & ESTRAD(pmol/L) & CORT(nmol/L) \\
\hline & $\mathrm{T} 1$ & $0.19 \pm 0.01^{\mathrm{a}}$ & $0.63 \pm 0.08^{\mathrm{a}}$ & $0.34 \pm 0.04^{c}$ & $73.30 \pm 0.00^{\mathrm{b}}$ & $5.38 \pm 0.13^{\mathrm{ab}}$ \\
\hline & $\mathrm{T} 2$ & $0.18 \pm 0.01^{\mathrm{a}}$ & $0.49 \pm 0.09^{\mathrm{b}}$ & $0.47 \pm 0.12^{\mathrm{b}}$ & $84.27 \pm 10.94^{\mathrm{ab}}$ & $5.50 \pm 0.00^{\mathrm{a}}$ \\
\hline & $\mathrm{T} 3$ & $0.17 \pm 0.01^{\mathrm{b}}$ & $0.68 \pm 0.11^{\mathrm{a}}$ & $0.32 \pm 0.10^{c}$ & $91.53 \pm 18.23^{\mathrm{a}}$ & $5.33 \pm 0.18^{\mathrm{ab}}$ \\
\hline & $\mathrm{T} 4$ & $0.17 \pm 0.01^{b}$ & $0.54 \pm 0.09^{\mathrm{ab}}$ & $0.60 \pm 0.23^{\mathrm{a}}$ & $73.30 \pm 0.00^{b}$ & $5.40 \pm 0.10^{\mathrm{a}}$ \\
\hline IB & & $0.17 \pm 0.01$ & $0.53 \pm 0.07^{\mathrm{b}}$ & $0.43 \pm 0.12$ & $78.77 \pm 5.47^{b}$ & $5.44 \pm 0.06^{\mathrm{a}}$ \\
\hline $\mathrm{HB}$ & & $0.18 \pm 0.01$ & $0.64 \pm 0.06^{\mathrm{a}}$ & $0.43 \pm 0.07$ & $82.41 \pm 9.11^{\mathrm{a}}$ & $5.36 \pm 0.09^{\mathrm{ab}}$ \\
\hline IBx & $\mathrm{T} 1$ & $0.19 \pm 0.00^{\mathrm{a}}$ & $0.55 \pm 0.13^{\mathrm{b}}$ & $0.28 \pm 0.05^{\mathrm{b}}$ & $73.30 \pm 0.00$ & $5.25 \pm 0.25$ \\
\hline $\mathrm{HBx}$ & $\mathrm{T} 1$ & $0.18 \pm 0.01^{\mathrm{ab}}$ & $0.72 \pm 0.07^{\mathrm{a}}$ & $0.39 \pm 0.01^{\mathrm{b}}$ & $73.30 \pm 0.00$ & $5.50 \pm 0.00$ \\
\hline IBx & $\mathrm{T} 2$ & $0.19 \pm 0.00^{\mathrm{a}}$ & $0.51 \pm 0.18^{\mathrm{c}}$ & $0.35 \pm 0.12^{\mathrm{b}}$ & $95.18 \pm 21.88$ & $5.50 \pm 0.00$ \\
\hline $\mathrm{HBx}$ & $\mathrm{T} 2$ & $0.17 \pm 0.02^{b c}$ & $0.48 \pm 0.14^{\mathrm{c}}$ & $0.59 \pm 0.19^{\mathrm{a}}$ & $73.30 \pm 0.00$ & $5.50 \pm 0.00$ \\
\hline IBx & $\mathrm{T} 3$ & $0.16 \pm 0.04^{c}$ & $0.59 \pm 0.21^{\mathrm{b}}$ & $0.24 \pm 0.15^{\mathrm{b}}$ & $73.30 \pm 0.00$ & $5.50 \pm 0.00$ \\
\hline $\mathrm{HBx}$ & $\mathrm{T} 3$ & $0.19 \pm 0.00^{\mathrm{a}}$ & $0.77 \pm 0.09^{\mathrm{a}}$ & $0.40 \pm 0.16^{\mathrm{b}}$ & $109.75 \pm 36.45$ & $5.15 \pm 0.35$ \\
\hline IB $x$ & $\mathrm{~T} 4$ & $0.15 \pm 0.05^{\mathrm{c}}$ & $0.47 \pm 0.16^{\mathrm{c}}$ & $0.86 \pm 0.36^{\mathrm{a}}$ & $73.30 \pm 0.00$ & $5.50 \pm 0.00$ \\
\hline
\end{tabular}


International Journal of Agriculture and Environmental Research

ISSN: 2455-6939

Volume: 07, Issue: 01 "January-February 2021"

\begin{tabular}{|c|c|c|c|c|c|}
\hline $\mathrm{T} 4$ & $0.19 \pm 0.00^{\mathrm{a}}$ & $0.61 \pm 0.09^{b}$ & $034 \pm 0.22^{b}$ & $73.30 \pm 0.00$ & $5.30 \pm 0.20$ \\
\hline Breed & NS & $*$ & NS & $*$ & $*$ \\
\hline $\mathrm{T} \times \mathrm{B}$ & $*$ & $*$ & $*$ & NS & NS \\
\hline
\end{tabular}

$\mathrm{a}, \mathrm{ab}, \mathrm{b}, \mathrm{c}=$ Means on the same column for each factor and their interactions, but with different superscripts are statistically $(\mathrm{P}<0.05)$ Significant. T1 $=$ Diet with $0.00 \%$ ASA; T2 $=$ Diet with $0.025 \%$ ASA; T3 = Diet with $0.050 \%$ ASA; T4 = Diet with $0.075 \%$ ASA; HB $=$ Harco Black; IB = Isa Brown; $\mathrm{B}=$ Breed; $\mathrm{T}=$ Treatment $\mathrm{B} \times \mathrm{T}=$ Breed $\times$ Treatment; NS = Not significant; Sig =Significant; $*=$ Significant at $0.05 \% ; \mathrm{LH}=$ Luteinizing hormone; $\mathrm{PROG}=$ Progesterone, $\mathrm{TEST}=$ Testoterone, ESTR $=$ Estradiol 
International Journal of Agriculture and Environmental Research

ISSN: 2455-6939

Volume: 07, Issue: 01 "January-February 2021"

\section{CONCLUSION}

Supplementation of acetylsalicylic acid up $0.050 \%$ in layer's diet has a significant effect in stimulating follicular growth and modulating the functionality of the oviduct.

\section{REFERENCES}

Ahmad-Ali, Mohammadpour, Abdolkarim, Zamanimoghadam, and Massoumeh Heidari (2012). Comparative histomorphometrical study of genital tract in adult laying hen and duck. Veterinary Research forum winter, 3 (1): 27-30.

Aro, S. O., Owokotomo, E. P. and Adebayo, A. D. (2015). The effects of varying levels of dietary salt on performance and faecal parameters of late production layers. Proceedings of the $40^{\text {th }}$ Annual Conference of the Nigerian Society for Animal Production, 15-19th March 2015, NAPRI/ABU, Zaria. Pp.: 407-410.

Aro S.O. (2019). Dietary salt potentiates folliculogenesis and modulates the functionality of the oviduct in late production layers. nigerian journal ofanimal science vol 21 no $3 \mathrm{pp}$

Balog, J.M. and P.Y. Hester, (1991). Effect of dietary acetylsalicylic acid on egg-shell quality. Poultry Science, 70: 624-630.

Climatic Data (2018). National centre for environmental information. State of the climate:global climate report for annual 2018. Htpps://www.ncdc.noaa.gov/sotc/global/201813

Corzo, A., Schilling, M. W. Loar, R. E. Jackson, V., Kin S. and Radhakrishnan, V. (2009). The effects of feeding distillers dried grains with solubles on broiler meat quality. Poultry Science, 88: 432-439.

El-Tarabany, M. S.(2016). Impact of temperature-humidity index on egg-laying characteristics and related stress and immunity parameters of Japanese quails. International Journal of Biometeorolology, 60: 957-964.

Fouad, A.M., Chen, W. Ruan., D. Wang., S., Xia.,W. G. and. Zheng, C. T.(2016). Impact of heat stress on meat, egg quality, immunity and fertility in poultry and nutritional factors that overcome these effects: A review. International Journal of Poultry Science, 15: 81-95.

Garriga, C., Hunter, R.R., Amat, C., Planas, J.M., Mitchell, M.A. and Moreto, M. ( 2006). Heat stress increases apical glucose transport in the chicken jejunum. Animal Journal of Physiology, 90: 195-201. 
International Journal of Agriculture and Environmental Research

ISSN: 2455-6939

Volume: 07, Issue: 01 "January-February 2021"

Gowe, R.S. and Fairfull, R.W. (2008). Breeding for resistance to heat stress. In: Poultry Productionin hot climates, Daghir, N.J. (Ed.). 2nd Edn., Cab International, Oxfordshire, UK., pp: 11-29.

Grieve, D. (2003). Heat stress in commercial layers and breeders. Technical Bulletin, Hy-Line International.http://www.neobio.biz/database/n-5data5-1/n-5data5-1-6.pdf.

Hakan billigt, Itsuko furutas, and Aaron j. W. Hsuehs (1993). Estrogens inhibit and Androgens Enhance OvarianGranulosa Cell Apoptosis Division of Reproductive Biology, Department of Gynecology and Obstetrics, Stanford University School of Medicine, Stanford, California $94305-5317^{*}$ Endocriminology, vol 133 no 5 https//www. researchgate. Net/ publication 14793981

Iwu, A. N. Ebere, C. S., Ogbuewu, I. P., Etuk, I. F., Opara, M. N., Uchegbu, M. C., Okoli, I. C. Iheukwumere, F.C. and Herbert, U. (2013). Coconut Shell Ash as a Mild Agonist of reproductive Organ Development and Sex Hormone Release in Growing Rabbits. Journal of Medical Sciences. 13: 563-570.

Kamboh, A.A., Hang, S.Q., Bakhetgul, M. and Zhu, W.Y. (2013). Effects of genistein and hesperidin on biomarkers of heat stress in broilers under persistent summer stress. Poultry Science, 92:2411-2418.

Oktem, O. and Urman, B. (2010). Understanding follicle growth in vivo. HumanReproduction. 25 (12): 2944-2954 5. Begin, J. J. and Johnson, T. H. (1976). Effect of dietary salt on the performance of laying hens. Poultry Science. 55(6): 2395-2404.

Oluyemi, J. A. and Adebanjo .A.(1979). Measures applied to combat thermal stress in poultry under practical tropical environment. Poultry Science, 58: 767-773.

Osinowo, O. A. (2006). Introduction to Animal Reproduction. 1st Edn., Sophie Academic Services Limited, Abeokuta, Nigeria, pp: 91.

Piestun, Y., Druyan, S., Brake, J. and Yahav, S. (2013). Thermal manipulations during broiler incubation alter performance of broilers to 70 days of age. Poultry Science, 92:11551163.

Quinteiro-Filho, W.M., Ribeiro, A., Ferraz-de-Paula, V., Pinheiro, M.L., Sakai, M., Ferreira, A. J. and Palermo-Neto, J. (2010).Heat stress impairs performance parameters, induces intestinal injury, and decreases macrophage activity in broiler chickens. Poultry Science, 89:1905-1914. 
Quinteiro-Filho, W.M., Gomes, A.V., Pinheiro, M.L., Ribeiro, A., Ferraz-de-Paula, V., AstolfiFerreira, C.S., Ferreira, A.J. and Palermo-Neto J. (2012.). Heat stress impairs performance and induces intestinal inflammation in broiler chickens infected with SalmonellaEnteritidis. Avian Patholobgy,41:421-427.

Reid, B. L., Kurnick, A.A., Thomas, J.M. and Hulett, B. J. (1964). Effect of Acetylsalicylic Acid and oxytetracycline on the performance of White Leghorn breeders and broiler chicks. Poultry Science, 43: 880-884.

Sakata, M., Kobayashi, H., Sun, G.W. et al. (2000) Ryudocan expression by luteinized granulosa cells is associated with the process of follicle atresia. Fertil. Steril.74 , 1208-1214.

SAS (2008). Statistical Analysis System, SAS Institute Inc. Cary, NC., USA.

St-Pierre, N. R., Cobanov, B. and Schnitkey, G. (2003). Economic losses from heat stress by US livestock industries. Journal of Dairy Science, 86 (E. Suppl.):E52-E77.

Watson A. J. (2007). Oocyte cytoplasmic maturation: a key mediator of oocyte and embryo developmental competence 1. J Anim Sci.; E1-E3. doi: 10.2527/ jas.2006-432.

Williams C. J. and Erickson A. (2000). Morphology and physiology of ovary. GF.In: Feingold KR, Anawalt B, Boyce A, Chrousos G, Dungan K, Grossman A, Hershman JM, Kaltsas G, Koch C, Kopp P, Korbonits M, McLachlan R, Morley JE, New M, Perreault L, Purnell J, Rebar R, Singer F, Trence DL, Vinik A, Wilson DP, editors. Endotext [Internet]. South Dartmouth (MA): MDText.com, Inc.; 